University of Nebraska - Lincoln

DigitalCommons@University of Nebraska - Lincoln

$6-2002$

\title{
Concurrent Infections and the Community Ecology of Helminth Parasites
}

John J. Janovy Jr.

University of Nebraska - Lincoln, jjanovy1@unl.edu

Follow this and additional works at: https://digitalcommons.unl.edu/bioscijanovy

Part of the Parasitology Commons

Janovy, John J. Jr., "Concurrent Infections and the Community Ecology of Helminth Parasites" (2002). John Janovy Publications. 5.

https://digitalcommons.unl.edu/bioscijanovy/5

This Article is brought to you for free and open access by the Papers in the Biological Sciences at DigitalCommons@University of Nebraska - Lincoln. It has been accepted for inclusion in John Janovy Publications by an authorized administrator of DigitalCommons@University of Nebraska - Lincoln. 


\title{
CONCURRENT INFECTIONS AND THE COMMUNITY ECOLOGY OF HELMINTH PARASITES
}

\author{
John Janovy Jr., \\ School of Biological Sciences, University of Nebraska-Lincoln, Lincoln, Nebraska 68588-0118. email: jjanovy1@unl.edu
}

In the early 1960s, John Holmes published 3 papers from his doctoral dissertation research, started at Rice University under the incisive supervision of Asa Chandler and completed under the equally incisive, if somewhat ornery, eyes of Clark P. Read. The first of these papers (Holmes, 1961; reprinted herein), established conclusively that 2 species of parasites interacted with one another in their common environment, such interaction being prerequisite to application of the "community" concept. This paper thus marks the beginning of modern community ecology as applied to parasitic helminths. The second paper (Holmes, 1962a) further defined the nature of interactions between Hymenolepis diminuta and Moniliformis dubius (= moniliformis). But if Holmes (1961, 1962a) established helminth community ecology as a rich, legitimate, and useful subdiscipline of parasitology, then Holmes (1962b) cast an intriguing shadow over his own results, for the 2 parasites did not interact with one another in the hamster as they did in the rat. Thus, the 1962 papers told us that the secrets of symbiont interspecific relationships would not be easily revealed and, more importantly, that system-specific effects could easily be the rule rather than the exception. After all, only 2 species of rodents were involved and only 2 species of helminth parasites; who could predict what might happen when similar studies were done with a hundred species of each? One can imagine Clark Read sitting in an easy chair late at night, smiling under his dark mustache, smoking with Hollywood type-cast ease, and completing his first reading of the draft dissertation. This stack of paper is indeed a seminal work, he probably concluded; thus, the smile. But the hamster section is really interesting, he might well have thought; thus, the eyes narrowed, Read-like crinkles forming at their corners, his smile widening, and the fire flaring as he took a deep drag.

Perhaps it is somewhat blasphemous to imagine Read's response to Holmes' graduate research, but in the grand tradition of parasitology, we can almost hear him saying: "the rat work is so impressive, so consistent with what we want to have happen in nature, that the broader scientific community is likely to ignore completely the results of those hamster experiments." And, as predicted in our imaginary scenario, the host-specific nature of Holmes' published results continued to be a matter of discussion over the next 4 decades, especially among those whose primary interest was parasitology, and who would therefore be cautious when approaching natural symbiotic systems. However, those who considered themselves "ecologists" grasped eagerly at the more paradigmatic implications of Holmes (1961) and Holmes (1962a) - after all, interspecific interactions are the factors that convert assemblages into communities, and if terminology is a reflection of underlying assertion, then we routinely assume interactions, or at least some kind of structuring mechanism, because the word "assemblage" is used only rarely nowadays. Indeed, the American Society of Parasitologists ad hoc terminology committees have consistent- ly recommended use of the term "community" (Bush et al., 1997) to describe concurrent infections with different parasite species.

Since Holmes (1961, 1962a, 1962b), parasite community ecology, and parasite ecology in general, has been shaped by 5 over-reaching concerns: (1) the question of whether members of parasite communities truly interact, (2) the search for patterns in nature that would reveal processes determining parasite community structure, (3) appropriate quantitative methods for describing and comparing communities, (4) development of models for generating hypotheses about community organizing processes, and (5) a search for systems amenable to testing these hypotheses. To date, nobody has managed to link these concerns together into a central unifying theme, the most likely reasons being the large number of factors that influence parasite diversity and distribution and the near impossibility of using so many host-parasite systems experimentally, especially in anything remotely resembling a natural setting.

Do different parasite species interact directly with one another, and if so, what is the nature of such interaction? Infection site is the context of our attempts to answer these questions. Interactions between community members are predicted when they obviously share a common resource, e.g., intestinal lumen or gill filaments; however, when different parasite species occur in different tissues, the opportunity for, and the very nature of, potential interaction is not at all obvious. If parasite species interact, the outcome can take various forms, including spatial displacement or reduction in numbers and biomass of one or more participants. If parasite species do not interact, they exist in relative isolation from one another, thus the term "isolationist" to describe such communities. These 2 possibilities formed the basis of a long-running, good-natured debate between John Holmes and Peter Price over the question of whether parasite communities were interactive or isolationist (Holmes, 1973; Price, 1980; Holmes and Price, 1986; Holmes, 1987; Price, 1987). This debate remains largely unresolved for 2 reasons: experimental designs using multispecies communities are logistical nightmares, or black holes, depending on your preferred metaphor (Simmons and Laurie, 1972; Holland, 1987), and a multiplicity of factors determine the abundance and distribution of parasites in nature.

Holmes initially maintained that parasites occupying a common habitat, e.g., the vertebrate intestine, often interacted with one another, citing examples from elasmobranchs, bony fish, amphibians, birds, and mammals (Cross, 1934; Kisielewska, 1970; Simmons and Laurie, 1972; Holmes, 1973). Furthermore, he and his students compiled a massive body of data on natural systems and presented their observations quite forcefully, thus setting the content and sampling standards for studies on parasite communities in nature (e.g., Bush and Holmes, 1986a, 1986b; Stock and Holmes, 1988). Price (1980), on the other hand, claimed that most often, parasite communities were really 
assemblages in which species simply co-occurred without interacting. Price (1980) cited numerous works of "noninteractive [parasite] coexistence" and reinterpreted some oft-cited studies (Schad, 1963a). In the process, he suggested that a particular habitat within a host, for example an intestine, might actually support more parasite species than were found within the community. Thus was born the concept of the vacant niche.

Neither side of this debate won, in part, perhaps, because of the species-specific nature of parasite communities and their hosts, as suggested by the comparison between Holmes' 2 papers $(1961,1962 \mathrm{~b})$, and we now admit there is a continuum of interactiveness in parasite communities (Goater et al., 1987; Cabaret and Hoste, 1998; Dove, 1999). Nevertheless, the Holmes and Price discussions had important evolutionary implications, presenting ideas that have yet to be explored fully and which might never be explored to our satisfaction because the methodology is not particularly obvious. Underlying the debate over proximal organizing mechanisms was a more basal discussion of how species lists for a particular host were assembled over evolutionary time. The various ideas arising out of this discussion, some borrowed with modification from the general ecological literature, are summarized in Price (1987, Table I), and that paper, along with its companion piece (Holmes, 1987), explains the issues beautifully. At least 2 of the evolutionary scenarios do not invoke interactions at any time during the assembly of a parasite list typical of some host species, postulating instead that parasites are either simply not available (for whatever reason) for membership in a community or are so specialized already that competition is not a restraint on their colonization of new hosts. Other models invoke competition at various times during community assembly in both evolutionary and ecological time. Although the "Ghost of Competition Past" is virtually impossible to find, Price (1987) suggests that we could sort through the various evolutionary scenarios by answering certain questions (he gives 5). Nothing in the published record since 1987 indicates that anyone has systematically set about to answer this list of questions for any one parasite community.

Intermediate host availability and transmission environment (typically dictated by abiotic conditions), and host and infection site specificity (the primary biotic factors in most parasitic relationships) all have major influences on the species richness and relative abundance in parasite communities. This mix of factors presents us with a large problem when we try to design heuristic evolutionary models, mainly because, ideally, we must account for past ecological factors that either threw parasite species together in some common resource, i.e., set the stage for interaction, or kept them apart spatially or temporally. For example, although intestinal helminths are typically at least somewhat host- and infection site-specific, studies of natural systems often seem to produce more positive than negative interactions (Dobson and Pacala, 1992; Bucknell et al., 1996; Luque et al., 1996; Cabaret and Hoste, 1998; Luque and Chaves, 1999; Sanmartin et al., 2000). Positive interactions are most readily attributed to ecological factors, i.e., transmission conditions, as in the Kehr et al. (2000) studies of helminths in South American frogs (Lysapsus linellus; Pseudidae), showing that positive associations were habitat dependent. Interactions often cannot be detected even when parasites share a resource, e.g., Janovy et al. (1997) reported no correlations between in- frapopulations of monogenes, myxozoans, and Trichodina sp. on Fundulus zebrinus gills; however, significant positive correlations did occur between infrapopulations of 2 Gyrodactylus species: one on the gills and one on the body surface, again suggesting transmission conditions were the primary community organizing factor.

Finally, in a number of papers, Poulin and coworkers (Poulin, 1995, 1996; Poulin and Rohde, 1997) have tried to separate the effects of phylogeny and ecology in providing structure to parasite communities. The 2 important questions are: Why is a particular species of parasite in a particular species of host, and what factors produce the distribution of parasites among available hosts at the time the host population is sampled? For a particular locality and host population, phylogeny provides an answer to the first question only if 2 conditions hold; namely, that infective stages of all parasite species capable of infecting a host are in the host's habitat and that habitat is stable enough to eliminate local transmission dynamics as a causal factor. Phylogeny is relevant to the second question only if the various parasite species have traits that predispose them to compete with one another, as may have been the case in the original Holmes' (1961) study.

The second concern, the search for process in pattern, has generated a rich and fascinating literature, temporarily culminating in a landmark volume titled, appropriately, Parasite Communities: Patterns and Processes (Esch et al., 1990). Since 1990 , the search for process has continued unabated, even perhaps stimulated by Esch et al. (1990). Host-parasite systems are usually chosen because of what they can "tell" an investigator, and sampling strategy then becomes the defining element of the study. Typical community structuring processes revealed by such research include, as a minimum, host longevity, size, and diet (Blaylock et al., 1998; Lo et al., 1998; Morand et al., 2000); shared intermediate hosts (Bush and Holmes, 1986a); the size of the available parasite pool (Vidal-Martinez et al., 1998); time and variable abiotic conditions, with the attendant effect on intermediate hosts (Janovy et al., 1997; Poulin and Rohde, 1997; Abu-Madi et al., 2000; Carney and Dick, 2000; Weichman and Janovy, 2000; Barger and Esch, 2001; Fedynich et al., 2001; Valtonen et al., 2001); the generalist versus specialist nature of parasites (Marcogliese and Cone, 1998; Zaffaroni et al., 1999); water temperature (Paperna, 1964); latitude (Rohde and Heap, 1998); and host phylogeny (Poulin, 1995). The length of this list might serve as a warning to those seeking evolutionary mechanisms applicable to parasites in general. Clearly, the forces that distribute parasite genetic variants among potentially selective environments are in themselves highly varied, and one cannot necessarily assume that these forces will remain stable enough over evolutionary time to allow for parasite evolutionary response. Holmes (1973) was probably right in focusing on infection site specificity as a major factor in structuring parasite communities, and Rohde's (1994) contention that mate-finding, rather than competition, is the driving force behind such specificity is also probably correct. Any assessment of interactions between parasite species in a common habitat must occur against this background of infection site specificity, and this is one of the main reasons Holmes' 1961 paper has such an enduring quality.

If the literature is an accurate reflection of our thinking, the third concern-appropriate quantitative descriptors for parasite 
communities-has evidently been addressed to the satisfaction of parasitologists. The terms "core" and "satellite" were borrowed from the ecologists (Hanski, 1982) then applied to parasite species with high and predictable prevalence versus low prevalence and sporadic occurrence, respectively (Bush and Holmes, 1986a, 1986b; Stock and Holmes, 1988). Various association, niche breadth, species diversity and community similarity indices, also borrowed from the mainstream ecological literature, were applied to parasite communities as a whole (Hair and Holmes, 1975; Edwards and Bush, 1989; Fedynich et al., 1997; Rigby et al., 1997; Smales and Cribb, 1997; Poulin, 1998; Dove, 1999; Zelmer and Esch, 1999; Byrne et al., 2000; Machado et al., 2000; Madhavi and Sai Ram, 2000; Simkovà et al., 2000). Although certainly useful in a purely descriptive sense, it is not at all clear what value the "core," "satellite," and "similarity" concepts have in either an evolutionary or ecological sense. In other words, they tell us what parasite communities look like and how similar they might be in terms of species makeup and relative proportions, but they tell us very little about evolutionary or ecological events that actually determine community structures. Parasites might be excellent material with which to link causality with description, however, because in many, if not most, cases we know how hosts acquire parasites; however, few studies, aside from those involving tropical diseases, go beyond the description-interpretation phase to actually determine ecological factors that control the flow of parasites into host populations.

Appropriate systems should allow us to distinguish between the various factors working to shape communities, but such systems are in short supply. A critical question, for example, is whether a parasite species shared by one or more hosts in ecological time is at least temporarily split into genetic variants according to host species occupied. Similarly, one might ask whether infrapopulations of a parasite species vary genetically depending on the combination of co-occurring parasite species. These questions have simply not been addressed for helminth communities. What we really need to know are the mechanisms by which parasite gene pools are either split or maintained in concurrent infections, and so far that knowledge is very rudimentary, especially for helminth communities. However, the many published quantitative descriptions of parasite communities, and the diversity of both hosts and parasites studied, provide a rich source of problems for future population geneticists interested in the evolution of symbiotic relationships. One truly remarkable study, albeit done at the whole-organism level, gives us an intriguing peak into this future. Reyda and Nickol (2001) showed that worms from a laboratory strain of Moniliformis moniliformis, separated from its wild source population for $31 \mathrm{yr}$ ( $\sim 60$ generations), freely interbred with worms from the wild source with no reduction in fecundity. Transposing the Reyda and Nickol (2001) approach to a parasite community such as that described by Stock and Holmes (1988) provides a glimpse of the challenge ultimately facing those who would try to answer some of the most difficult questions about the evolutionary forces providing structure to parasite communities.

The fourth concern of those studying parasite ecology is theory, exemplified by various mathematical models. Some of these models assume host population growth to be regulated by parasites (Dobson and Roberts, 1994; Roberts and Dobson, 1995), but others do not (Janovy et al., 1990), and still others focus on host phylogeny as a major contributor to parasite community makeup (Vickery and Poulin, 1998). The models are useful insofar as they suggest testable hypotheses, although the underlying assumptions must first be validated. For example, many factors other than parasitism can limit host population growth, and to date, only one set of studies has produced anything resembling relative risk tables-from field data-that would show how even a single parasite species might affect host populations in nature, compared to predation, annual fluctuations in climatic conditions, and pure bad luck (Hudson, Dobson, and Newborn, 1992, 1998; Hudson, Newborn, and Dobson, 1992; Dobson and Hudson, 1992; 1995). Gatto and DeLeo (1998) address this issue theoretically, however, showing that in host populations controlled by factors other than parasitism, both host numbers and parasite transmission mechanisms are the major factors providing structure to the parasite community. The Gatto and DeLeo (1998) results agree with those of Janovy et al. (1990, 1995), who suggest that appropriate parasite community models are ones in which the major factor is probability of infection that varies among parasite species. In all of these models, the evolutionary component is assumed, i.e., the potential parasite community is built from species that could infect the host if given an opportunity, and hostparasite encounter dynamics then determine distribution of parasites - both individuals and species-among members of a host population. To be an important structuring factor, therefore, interactions between parasite species would have to override the ecological events that distribute those same species into hosts.

The fifth and final concern of parasite ecologists, namely the search for systems amenable to experimental manipulation, is being actively pursued, possibly because surveys are so often excellent teaching devices for beginning graduate students (Banks and Ashley, 2000; Bolek and Coggins, 2000). In addition, the search for patterns that would reveal process is also, by default, a search for systems that could be used experimentally. We do not always think of inventories in this manner, but regardless of their various designs, such studies do tell us what species are available, how easy they are to sample and process, and what kinds of biotic interactions might be present in the system. Community structuring processes are sometimes thought to be most easily detected when relatively few parasite species are involved. Thus fish seem to be a favorite survey target, possibly because they are so often available in large numbers, their gills provide a natural and quantifiable habitat, and their parasite communities tend to be depauperate compared, for example, to those of some birds and mammals (Garcia and Canaris, 1987; Montgomery and Montgomery, 1990; Holmes and Bartoli, 1993; Guégan and Hugueny, 1994; Hartvigsen and Halvorsen, 1994; Beveridge et al., 1998; Zander et al., 1999; Choudhury and Dick, 2000; Machado et al., 2000; Perez-Ponce de Leon et al., 2000; di Cave et al., 2001; Gutierrez, 2001). Inventories have yet to yield a large number of systems that could be exploited experimentally, but we have a very long way to go before all potential host-parasite combinations are fully explored. If surveys and inventories would produce even one more system as useful as, but perhaps more economical than, the rat, Hymenolepis diminuta, and Moniliformis moniliformis combination, that discovery would benefit enormously the discipline of parasitology. 
A final comment needs to be made about the role of acanthocephalans in concurrent helminth infections. Price (1980) alluded to the possibility that acanthocephalans might have more of an impact on intestinal communities than other kinds of helminths. Although nobody has systematically explored that idea, a few subsequent studies suggest that acanthocephalan-cestode combinations might be particularly revealing of interspecific interactions (Duborow et al., 1988; Bates and Kennedy, 1990; Vidal-Martinez and Kennedy, 2000). If this is the case, then John Holmes' original choice of materials, made for whatever reason-ranging from insight to pure convenience, was a, if not the, key factor in the development of parasite ecology as we practice the discipline and interpret our results today.

\section{LITERATURE CITED}

Abu-Madi, M. A., J. M. Behnke, J. W. Lewis, And F. S. Gilbert. 2000. Seasonal and site specific variation in the component community structure of intestinal helminths in Apodemus sylvaticus from three contrasting habitats in south-east England. Journal of Helminthology 74: 7-15.

BANKS, S. M., AND D. C. Ashley. 2000. Observations on the internal helminth parasite fauna of largemouth bass, Micropterus salmoides, from Smithville Reservoir, Missouri. Journal of Freshwater Ecology 15: 299-306.

BARger, M., AND G. W. EsCh. 2001. Downstream changes in the composition of the parasite community of fishes in an Appalachian stream. Journal of Parasitology 87: 250-255.

BATES, R. M., AND C. R. KENNEDy. 1990. Interactions between the acanthocephalans Pomphorhynchus laevis and Acanthocephalus anguillae in rainbow trout: Testing an exclusion hypothesis. Parasitology 100: 435-444.

Beveridge, I., N. B. Chilton, P. M. Johnson, L. R. Smales, R. Speare, AND D. M. SPRATT. 1998. Helminth parasite communities of kangaroos and wallabies (Macropus spp. and Wallabia bicolor) from north and central Queensland. Australian Journal of Zoology 46: 473-495.

Blaylock, R. B., J. C. Holmes, and L. Margolis. 1998. The parasites of Pacific halibut (Hippoglossus stenolepis) in the eastern North Pacific. Canadian Journal of Zoology 76: 536-547.

BoleK, M. G., AND J. R. CoGGINs. 2000. Seasonal occurrence and community structure of helminth parasites from the Eastern American Toad, Bufo americanus americanus, from southeastern Wisconsin. Comparative Parasitology 67: 202-209.

Bucknell, D., H. Hoste, R. B. Gasser, and I. Beveridge. 1996. The structure of the community of strongyloid nematodes of domestic equids. Journal of Helminthology 70: 185-192.

Bush, A. O., AND J. C. Holmes. 1986a. Intestinal helminths of lesser scaup ducks: Patterns of association. Canadian Journal of Zoology 64: $132-141$.

, AND - 1986b. Intestinal helminths of lesser scaup ducks: An interactive community. Canadian Journal of Zoology 64: 142152.

, K. D. Lafferty, J. M. Lotz, and A. W. Shostak. 1997. Parasitology meets ecology on its own terms: Margolis et al. revisited. Journal of Parasitology 83: 575-583.

Byrne, C. J., C. Grey, C. Holland, and R. Poole. 2000. Parasite community similarity between four Irish lakes. Journal of Helminthology 74: 301-305.

CABARET, J., AND J. Hoste. 1998. Comparative analysis of two methods used to show interspecific associations in naturally acquired parasite nematode communities from the abomasum of ewes. Veterinary Parasitology 76: 275-285.

CARney, J. P., AND T. A. Dick. 2000. Helminth communities of yellow perch (Perca flavescens [Mitchill]): Determinants of pattern. Canadian Journal of Zoology 78: 538-555.

di Cave, D., F. Berrilli, C. De Liberato, P. Orecchia, and C. R. KenNEDY. 2001. Helminth communities in eels Anguilla anguilla from Adriatic coastal lagoons in Italy. Journal of Helminthology 75: 713.
Choudhury, A., AND T. A. Dick. 2000. Richness and diversity of helminth communities in tropical freshwater fishes: Empirical evidence. Journal of Biogeography 27: 935-956.

Cross, S. X. 1934. A probable case of non-specific immunity between two parasites of ciscoes of the Trout Lake region of northern Wisconsin. Journal of Parasitology 20: 244-245.

Dobson, A. P., AND P. J. HudSON. 1992. Regulation and stability of a free-living host-parasite system: Trichostrongylus tenuis in red grouse: II. Population models. Journal of Animal Ecology 61: 487498.

, AND -1995 . The interaction between the parasites and predators of red grouse Lagopus lagopus scoticus. Ibis 137(suppl. 1): S87-S96.

, AND S. W. Pacala. 1992. The parasites of Anolis lizards in the northern Lesser Antilles: II. The structure of the parasite community. Oecologia 91: 118-125.

— AND M. RoBeRTS. 1994. The population dynamics of parasitic helminth communities. Parasitology 109: S97-S108.

Dove, A. D. M. 1999. A new index of interactivity in parasite communities. International Journal for Parasitology 29: 915-920.

Duborow, R. M., W. A. Rogers, AND P. H. Klesius. 1988. Interaction of bass tapeworm, Proteocephalus ambloplitis, and Neoechinorhynchus sp. (Acanthocephala) in largemouth bass, Micropterus salmoides. Journal of Parasitology 74: 1056-1059.

EdwardS, D. D., AND A. O. BUSH. 1989. Helminth communities in avocets: Importance of the compound community. Journal of Parasitology 75: 225-238.

Esch, G. W., A. O. BuSh, AND J. M. AHO. 1990. Parasite communities: Patterns and processes. Chapman and Hall, London, U.K., 335 p.

Fedynich, A. M., T. Monasmith, and S. Demarais. 2001. Helminth community structure and pattern in Merriam's kangaroo rats, $D i$ podomys merriami Mearns, from the Chihauhan Desert of New Mexico. Comparative Parasitology 68: 116-121.

, D. B. Pence, and J. F. Bergan. 1997. Helminth community structure and pattern in sympatric populations of double-crested and neotropic cormorants. Journal of the Helminthological Society of Washington 64: 176-182.

Garcia, C. A., AND A. G. Canaris. 1987. Metazoan parasites of $R e$ curvirostra americana Gmelin (Aves), from southwestern Texas and Monte Vista National Wildlife Refuge, Colorado, with a checklist of helminth parasites hosted by this species in North America. The Southwestern Naturalist 32: 85-91.

Gatto, M., and G. A. DeLeo. 1998. Interspecific competition among macroparasites in a density-dependent host population. Journal of Mathematical Biology 37: 467-490.

GoATER, T. M., G. W. ESCH, AND A. O. Bush. 1987. Helminth parasites of sympatric salamanders: Ecological concepts at infracommunity, component and compound communities levels. American Midland Naturalist 118: 289-230.

GuÉGAN, J. F., AND B. Hugueny. 1994. A nested parasite species subset pattern in tropical fish: Host as major determinate of parasite infracommunity structure. Oecologia 100: $184-189$.

GutTIEREZ, P. A. 2001. Monogenean community structure on the gills of Pimelodus albicans from Rio de la Plata (Argentina): A comparative approach. Parasitology 122: 465-470.

Hair, J. D., AND J. C. Holmes. 1975. The usefulness of measures of diversity, niche width and niche overlap in the analysis of helminth communities in waterfowl. Acta Parasitologica Polonica 23: 253269.

HANSKI, I. 1982. Dynamics of regional distribution: The core and satellite species hypothesis. Oikos 38: 210-221.

Hartvigsen, R., and O. Halvorsen. 1994. Spatial patterns in the abundance and distribution of parasites of freshwater fish. Parasitology Today 10: $28-31$.

Holland, C. 1987. Interspecific effects between Moniliformis (Acanthocephala), Hymenolepis (Cestoda) and Nippostrongylus (Nematoda) in the laboratory rat. Parasitology 94: 567-581.

HolmES, J. C. 1961. Effects of concurrent infections on Hymenolepis diminuta (Cestoda) and Moniliformis dubius (Acanthocephala). I. General effects and comparison with crowding. Journal of Parasitology 47: 209-216.

1962a. Effects of concurrent infections on Hymenolepis dimi- 
nuta (Cestoda) and Moniliformis dubius (Acanthocephala). II. Effects on growth. Journal of Parasitology 48: 87-96.

. 1962b. Effects of concurrent infections on Hymenolepis diminuta (Cestoda) and Moniliformis dubius (Acanthocephala). III. Effects in hamsters. Journal of Parasitology 48: 97-100.

— 1973. Site selection by parasitic helminths: Interspecific interactions, site segregation, and their importance to the development of helminth communities. Canadian Journal of Zoology 51: 333347.

. 1987. The structure of helminth communities. International Journal for Parasitology 17: 203-208.

$\longrightarrow$, AND P. BARTOLI. 1993. Spatio-temporal structure of the communities of helminths in the digestive tract of Sciaena umbra L. 1758 (Teleostei). Parasitology 106: 519-525.

- AND P. W. PRICE. 1986. Communities of parasites. In Community ecology: Pattern and process, D. J. Anderson and J. Kikkawa (eds.). Blackwell Scientific Publications, Oxford, U.K., p. $187-213$

Hudson, P. J., A. P. Dobson, And D. Newborn. 1992. Do parasites make prey vulnerable to predation? Red grouse and parasites. Journal of Animal Ecology 61: 681-692.

- - - AND $\longrightarrow$ 1998. Prevention of population cycles by parasite removal. Science 282: 2256-2258.

$\longrightarrow$, D. NewBorn, AND A. P. Dobson. 1992. Regulation and stability of a free-living host-parasite system: Trichostrongylus tenuis in red grouse: I. Monitoring and parasite reduction experiments. Journal of Animal Ecology 61: 477-486.

Janovy, J. JR., R. E. Clopton, D. A. Clopton, S. D. SNyder, A. Efting, AND L. KREBS. 1995. Species density distributions as null models for ecologically significant interactions of parasite species in an assemblage. Ecological Modelling 77: 189-196.

- M. T. Ferdig, AND M. A. MCDowell. 1990. A model of dynamic behavior of a parasite species assemblage. Journal of Theoretical Biology 142: 517-529.

- S. D. SNyDER, AND R. E. Clopton. 1997. Evolutionary constraints on population structure: The parasites of Fundulus zebrinus (Pisces: Cyprinodontidae) in the South Platte River of Nebraska. Journal of Parasitology 83: 584-592.

Kehr, A. I., B. F. J. Manley, and M. I. Hamann. 2000. Coexistence of helminth species in Lysapsus limellus (Anura: Pseudidae) from an Argentinean subtropical area: Influence of biotic and abiotic factors. Oecologia 125: 549-558.

KISIELEWSKA, K. 1970. Ecological organization of intestinal helminth groupings in Cleithronomys glareolus (Schreb.) (Rodentia). V. Some questions concerning helminth groupings in the host individuals. Acta Parasitologica Polonica 18: 197-208.

Lo, C. M., S. MoRAnd, AND R. Galzin. 1998. Parasites diversity/host age and size relationship in three coral-reef fishes from French Polynesia. International Journal for Parasitology 28: 1695-1708.

Luque, J. L., J. F. R. Amato, AND R. M. TAKemoto. 1996. Comparative analysis of the communities of metazoan parasites of Orthoptristes ruber and Haemulon steindachneri (Osteichthyes: Haemulidae) from the southeastern Brazilian littoral: II. Diversity, interspecific associations, and distribution of gastrointestinal parasites. Revista Brasileira de Biologia 56: 293-302.

- AND N. D. Chaves. 1999. Community ecology of metazoan parasites of bluefish Pomatomus saltator (Linnaeus) (Osteichthyes, Pomatomidae) from the littoral of State of Rio de Janeiro, Brazil. Revista Brasileira de Zoologia 16: 711-723.

Machado, P. M., S. C. DE Almeida, G. C. Pavanelli, and R. M. TaKEмОTо. 2000. Ecological aspects of endohelminths parasitizing Cichla monoculus Spix, 1831 (Perciformes: Cichlidae) in the Parana River near Porto Rico, State of Parana, Brazil. Comparative Parasitology 67: 210-217.

Madhavi, R., AND B. K. SAI Ram. 2000. Community structure of helminth parasites of the tuna, Euthynnus affinis, from the Visakhapatnam coast, Bay of Bengal. Journal of Helminthology 74: 337342.

Marcogliese, D. J., AND D. K. Cone. 1998. Comparison of richness and diversity of macroparasite communities among eels from Nova Scotia, the United Kingdom, and Australia. Parasitology 116: 73 83.

Montgomery, S. S. J., AND W. I. Montgomery. 1990. Structure, sta- bility and species interactions in helminth communities of wood mice, Apodemus sylvaticus. International Journal for Parasitology 20: $225-242$.

Morand, S., T. H. Cribb, M. Kulbicki, M. C. Rigby, C. Chauvet, V. Dufour, E. FalieX, R. Galzin, C. M. Lo, A. Lo-yat, S. Pichelin, AND P. SASAL. 2000. Endoparasite species richness of New Caledonian butterfly fishes: Host density and diet matter. Parasitology 121: $65-73$.

PAPERNA, I. 1964. Competitive exclusion of Dactylogyrus extensus by Dactylogyrus vastator (Trematoda: Monogenea) on the gills of reared carp. Journal of Parasitology 50: 94-98.

Perez-Ponce De Leon, G., P. L. Garcia, R. V. Leon, and A. ChoudHURY. 2000. Helminth communities of native and introduced fishes in Lake Patzcuaro, Michoacan, Mexico. Journal of Fish Biology 57: 303-325.

Poulin, R. 1995. Phylogeny, ecology, and the richness of parasite communities in vertebrates. Ecological Monographs 65: 283-302.

. 1996. Richness, nestedness, and randomness in parasite community infrastructure. Oecologia 105: 545-551.

. 1998. Comparison of three estimates of species richness in parasite component communities. Journal of Parasitology 84: 485490.

, AND K. ROHDE. 1997. Comparing the richness of metazoan ectoparasite communities of marine fishes: controlling for host phylogeny. Oecologia 110: 278-283.

PRICE, P. W. 1980. Evolutionary biology of parasites. Princeton University Press, Princeton, New Jersey, 237 p.

. 1987. Evolution in parasite communities. International Journal for Parasitology 17: 209-214.

ReydA, F. B., AND B. B. Nickol. 2001. A comparison of biological performances among a laboratory-isolated population and two wild populations of Moniliformis moniliformis. Journal of Parasitology 87: $330-338$.

Rigby, M. C., J. C. Holmes, T. H. Cribb, and S. Morand. 1997. Patterns of species diversity in the gastrointestinal helminths of a coral reef fish, Epinephelus merra (Serranidae), from French Polynesia and the South Pacific Ocean. Canadian Journal of Zoology 75: $1818-1827$.

RoberTs, M. G., AND A. P. Dobson. 1995. The population dynamics of communities of parasitic helminths. Mathematical Biosciences 126: 191-214.

RoHDE, K. 1994. Niche restriction in parasites: Proximate and ultimate causes. Parasitology 109 (suppl.): S69-S84.

$\longrightarrow$, AND M. HEAP. 1998. Latitudinal differences in species and community richness in community structure of metazoan endo- and ectoparasites of marine teleost fish. International Journal for Parasitology 28: 461-474.

Sanmartin, M. L., M. F. Alvarez, D. Peris, R. Iglesias, and J. Leiro. 2000. Parasite community study of the undulate ray Raja undulata in the Ria of Muros (Galacia, northwest Spain). Aquaculture 184: 189-201.

SCHAD, G. A. 1963a. Niche diversification in a parasite species flock. Nature 198: $401-406$.

. 1963b. The ecology of co-occurring congeneric pinworms in tortoise, Testudo graeca. In Proceedings of the 16th International Congress of Zoology I, Washington, D.C., p. 949-1063.

Simkovà, A., Y. Desdevises, M. Gelnar, and S. Morand. 2000. Coexistence of nine gill ectoparasites (Dactylogyrus: Monogenea) parasitising the roach (Rutilus rutilus L.): History and present ecology. International Journal for Parasitology 30: 1077-1088.

Simmons, J. E., AND J. S. Laurie. 1972. A study of Gyrocotle in the San Juan Archipelago, Puget Sound, U.S.A., with observations on the host, Hydrolagus collei (Lay and Bennett). International Journal for Parasitology 2: 59-77.

Smales, L. R., AND T. H. CRIBb. 1997. Helminth parasite communities of the water-rat, Hydromys chrysogaster, from Queensland. Wildlife Research 24: 445-457.

STOCK, T. M., AND J. C. Holmes. 1988. Functional relationships and microhabitat distributions of enteric helminths of grebes (Podicipedidae): The evidence for interactive communities. Journal of Parasitology 74: 214-227.

Valtonen, E. T., K. Pulkkinen, R. Poulin, And M. Julkunen. 2001. 
The structure of parasite component communities in brackish water fishes of the northeastern Baltic Sea. Parasitology 122: 471-481.

Vickery, W. L., AND R. Poulin. 1998. Parasite extinction and colonisation and the evolution of parasite communities: A simulation study. International Journal for Parasitology 28: 727-737.

Vidal-Martinez, V. M., and C. R. Kennedy. 2000. Potential interactions between the intestinal helminths of the cichlid fish Cichlisoma synspilum from southeastern Mexico. Journal of Parasitology 86: 691-695. process of the macroparasite community of an experimental population of Cichlasoma urophthalmus through time. Journal of Helminthology 72: 199-207.
Weichman, M. A., AND J. JANOVY JR. 2000. Parasite community structure in Pimephales promelas (Pisces: Cyprinidae) from two converging streams. Journal of Parasitology 86: 654-656.

Zaffaroni, E., M. T. Manfredi, AND P. Lanfranchi. 1999. Effect of seasonality on abomasal helminth community in alpine ibex (Capra ibex ibex). Parassitologia 41: 567-572.

ZANDER, C. D., L. W. REIMER, AND K. BARZ. 1999. Parasite communities of the Salzhaff (Northwest Mecklenburg, Baltic Sea). I. Structure and dynamics of communities of littoral fish, especially small-sized fish. Parasitology Research 85: 356-372.

ZELMER, D. A., AND G. W. EsCh. 1999. Robust estimation of parasite component community richness. Journal of Parasitology 85: 592594. 